\title{
Design of Linear DC Motor Two-degree-of-freedom Positioning System using Model Reference type Sliding Mode Controller
}

\author{
Shiro Urushihara Member (Takamatsu National College Technology) \\ Takuya Kamano Member (The University of Tokushima) \\ Satoshi Yura Member (Takamatsu National College Technology) \\ Takashi Yasuno Member (The University of Tokushima) \\ Takayuki Suzuki Member (The University of Tokushima)
}

Keywords: linear DC motor, dead-band, sliding mode control, two-degree-of-freedom control, manabe polynomials

One of fundamental problems in the factory automation is how to obtain linear motion. Linear motors produce directly the linear motion force without a motion-transform mechanism. Linear d.c. motors (LDMs) have excellent performance and controllability. However, the dynamics of small-sized LDMs is adversely affected by the dead-band due to the friction between brushes and commutators.

In this paper, we describe the design of the two-degree-offreedom positioning system with a LDM using model reference type sliding mode controller (SMC). The proposed positioning system which is shown in Fig. 1 consists of a fixed gain feedforward controller and a SMC used as a feedback controller. The switchingplane of SMC is designed by Manabe Polynomials and the nominal parameters of the tested LDM. The objective of the SMC is to repress the influence of nonlinear characteristics (the dead-band and parameter variations etc.). The tracking performance can be improved as the fixed gain feedforward controller makes a dynamic inverse system in the feedforward path. Fig. 2(a) and (b) show the experimental results of the proposed system for square wave signal, as input signal for refference model, of which amplitude is $0.3(\mathrm{~m} / \mathrm{s})$. The actual output follows the output of refference model, and the tracking error is almost zero.

The effectiveness of the proposed system for improvement of the tracking performance is demonstrated by these experimental results.

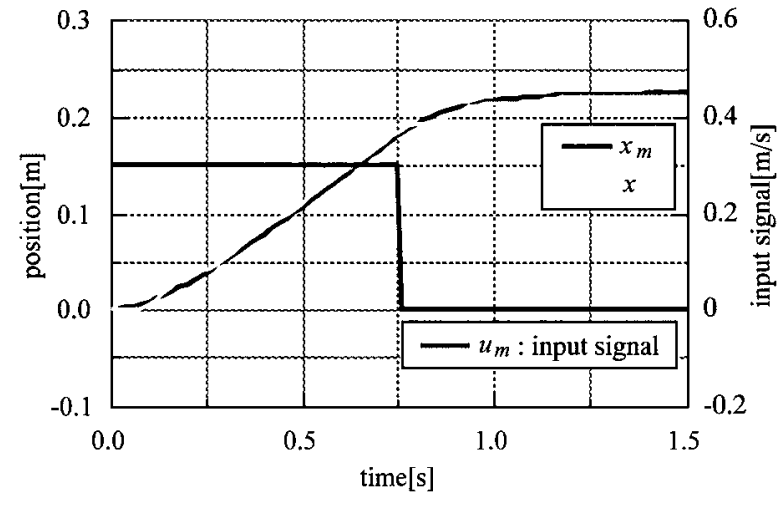

(a) Desired output and actual output

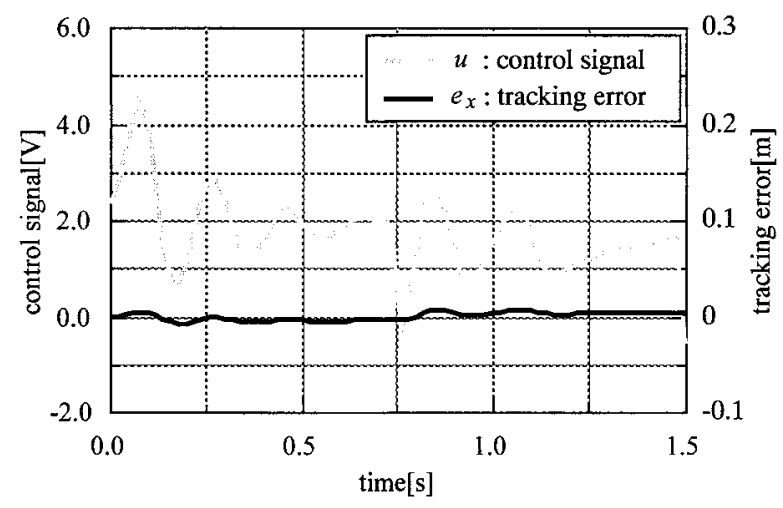

(b) Control signal and tracking error

Fig. 2. Experimental results for step-input

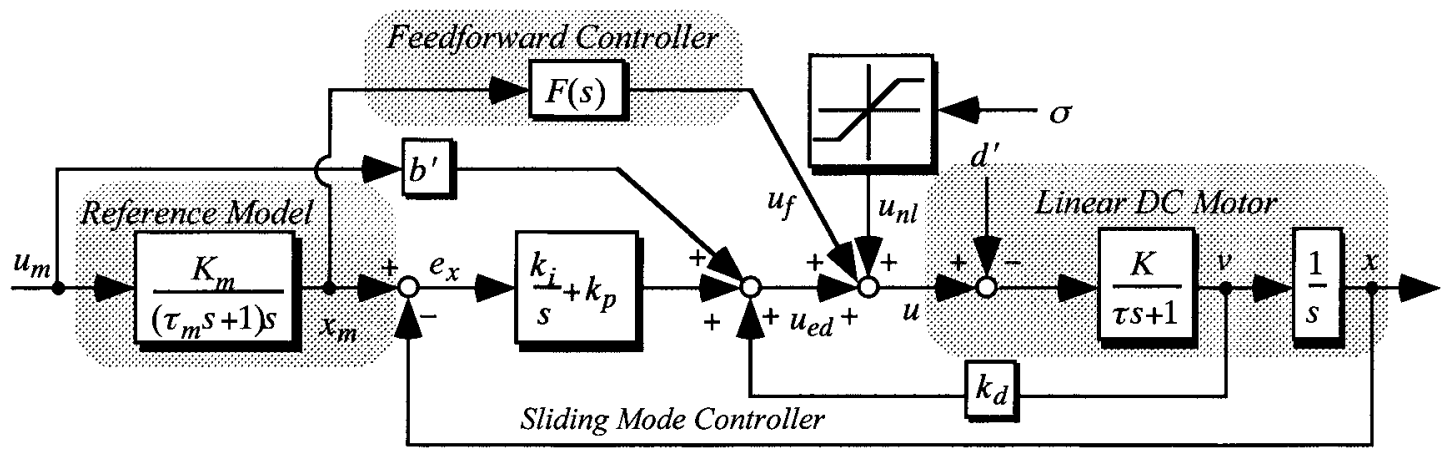

Fig. 1. Block diagram of proposed positioning system 


\title{
モデル規範形SMCを用いた \\ リニア DCモータ 2 自由度位置決めシステム設計法
}

$\begin{array}{llcccr}\text { 正員 漆原 } & \text { 史朗* } & \text { 正 員 鎌野 } & \text { 琢也** } \\ \text { 正員 由良 } & \text { 諭* }^{*} \text { 正員 安野 } & \text { 卓** } \\ \text { 正 員 鈴木 } & \text { 茂行** } & & & \end{array}$

\author{
Design of Linear DC Motor Two-degree-of-freedom Positioning System \\ using Model Reference type Sliding Mode Controller \\ Shiro Urushihara*, Member, Takuya Kamano**, Member, Satoshi Yura*, Member, \\ Takashi Yasuno**, Member, Takayuki Suzuki**, Member
}

\begin{abstract}
One of fundamental problems in the factory automation is how to obtain linear motion. Linear motors produce directly the linear motion force without a motion-transform mechanism. Linear d.c. motors (LDMs) have excellent performance and controllability. However, the dynamics of small-sized LDMs is adversely affected by the dead-band due to the friction between brushes and commutators.

In this paper, it is described that the design of the two-degree-of-freedom positioning system with a LDM using model reference type sliding mode controller (SMC). The proposed positioning system consists of a fixed gain feedforward controller and a SMC used as a feedback controller. The objective of the SMC is to repress the influence of nonlinear characteristics (the dead-band and parameter variations etc.). The tracking performance can be improved as the fixed gain feedforward controller makes a dynamic inverse system in the feedforward path. The effectiveness of the proposed system for improvement of the tracking performance is demonstrated by experimental results.
\end{abstract}

キーワード : リニア DC モータ, 不感帯, スライディングモード制御, 2 自由度制御, 真鍋多項式

Keywords: linear DC motor, dead-band, sliding mode control, two-degree-of-freedom control, manabe polynomials

\section{1. まえがき}

一般に, 搬送システム, FA 機器および OA 機器等にお いて直進運動を必要とする場合が多い。従来の用途では回 転形モー夕と直線変換機構などで直線運動を得ていたため に，装置が複雑となり小型化が困難であった。そこで，補 助機構を介することなく直接, 直進運動の得られるリニア DC モータのニーズが高まっている(1)(2)。しかしながら，小 型リニア DC モータにおいては，ブラシと整流子間の摩擦 による不感帯の影響が問題となり，本リニアモー夕は負荷 を直接駆動するため，動特性が摩擦の影響により大幅に変 動すると考えられる。それゆえ，本モー夕を用いて高精度

\footnotetext{
*高松工業高等専門学校

下 761-8058 高松市勅使町 355

Takamatsu National College of Technology

355, Chokushi-cyo, Takamatsu 761-8058

** 徳島大学

干 770-8506 德島市南常三島町 2-1

The University of Tokushima

2-1, Minamijosanjima-cho, Tokushima 770-8506
}

の位置決めシステムを構成するためには，摩擦の影響や動 特性の変動を十分に抑圧し, 良好な位置決め特性を得るコ ントローラが必要となる。

近年，十分な外乱抑圧特性と良好な位置決め特性を両立 するシステムとしてインテリジェント制御手法や外乱オブ ザーバを用いたシステムが提案され成果を上げている ${ }^{(3)}$ (5)。 筆者らは，インテリジェント制御の一手法としてニューラ ルネットワーク, 自己調整ファジィコントローラを用いた 位置決めシステムについても検討してきた。インテリジェ ントコントローラにより制御対象の非線形特性を含めた逆 システムをフィードフォワードパス内に構成することによ り摩擦等の外乱を抑圧しつつ位置決め特性の改善を図った。 これら手法においては, 学習に時間を要すること, 安定性解 析が困難であること等の問題がある。また，外乱オブザー バは, 既に 6 自由度のモータステージを持つシステムに応 用され有効な結果を与えている。外乱オブザーバを用いた 手法においては, 摩擦等を含めた外乱トルクをアクチュエー タのトルク方程式に基づいて補償し, 制御対象の動特性を ノミナル值に固定できる。しかしながら，本リニアモータ 
に対して外乱オブザーバを適用する場合，整流子とブラシ の工作精度や電気的時定数が小さいため電機子電流が断続 すること，また，回転形直流機と比較して低速で動作する ため高精度な速度検出が得られ難い等の問題がある。

一方，近年非線形システムに対する可变構造制御は, 制 御対象の各状態量を設計した切換平面に拘束し，不確かさ を含む系に対する優れたロバスト性を実現する制御法とし て注目されている(6) (10)。この可変構造制御理論の中で最も 理論的に体系化されているのがスライディングモード制御 理論 (11) であり, 最大の弱点であったチャタリングも克服さ れシステムの安定化やサーボ系の設計論として脚光を浴び ている。スライディングモード制御は，希望の特性を切換 平面として設計すれば，システムは等価的に望ましい特性 に拘束される。ここでは，スライディングモード制御の設 計手順として，切換平面により算出される等価制御入力と 切換平面に拘束させるための切換制御入力を設計すること になる。

本稿では，摩擦の影響が応答特性に顕著に現れるリニア DC モータを対象とし，モデル規範形スライディングモー ドコントローラ（以下 SMC）を用いた 2 自由度位置決め システムの設計法について述べている。提案するシステム は，外乱抑圧を目的としたモデル規範形 SMC と応答特性 の改善を目的とする固定ゲインフィードフォワードコント ローラによって構成されている。リニアモータの望ましい 動特性を規範モデルとして与え，モデルの出力にリニアモー 夕の出力位置が一致するように各コントローラの設計を行 う。モデル規範形 SMC の等価制御入力は，係数図法の一 手法である真鍋多項式 (12) (14) を用いた切換平面の設計を行 うことにより導出する。切換制御入力の設計法では，チャ タリングを防止するために飽和関数を用いた手法について 検討している。また，システム設計の際に，摩擦による非 線形特性に加えパラメー夕変動の影響を等価外乱とみなし, マッチング条件を満足していることを確認している。その ため，モデル規範形 SMC により等価外乱が十分抑圧され るとリニアモータの伝達特性は公称值で表される線形特性 に固定できる。そこで，規範モデルの入力からリニアモー 夕の出力位置までの伝達特性を規範モデルと一致するよう にフィードフォワードコントローラを設計することにより， 良好な目標值追従特性を得ることができる。フィードフォ ワードコントローラを付加することにより理論上規範モデ ルを任意に設定できることになる。しかしながら，現実的 にはハードウェアの制限を受け, 設定範囲は限られること になる。

以下では，まず，供試リニアモー夕の非線形特性とパラ メー夕変動の影響を等価外乱として定義し，基本方程式か ら状態方程式を導出している。さらに, 規範モデル, SMC ならびにフィードフォワードコントローラの設計手順につ いて述べている。実測結果を基に外乱抑圧特性と位置決め 特性について検証し, 提案する 2 自由度位置決めシステム の有用性について考察している。

\section{2. リニア DC モータの特性}

〈2・1〉リニア DC モータ＼cjkstart本リニアモータの電圧方 程式および推力方程式は (1)〜 (3) 式で与えられる。ただし, 機械的時定数に比較して電気的時定数が十分小さいため電 機子巻線インダクタンスを無視して電圧方程式を導出して いる。

$$
\begin{aligned}
& u=R_{a} i+v_{b}+K_{v} v \ldots \ldots \\
& K_{t} i=M \frac{d v}{d t}+F_{v} v+t_{c}+t_{l} \\
& \frac{d x}{d t}=v \ldots \ldots \ldots \ldots \ldots
\end{aligned}
$$

ここで, $u$ : 電機子電圧 (制御信号) $, i:$ 電機子電流, $R_{a}:$ 電 機子抵抗, $v_{b}$ : ブラシ電圧降下, $K_{v}$ : 逆起電力定数, $v$ : 速 度, $K_{t}$ : 推力定数, $M$ : モー夕の質量, $F_{v}$ : 粘性摩擦力係 数, $t_{c}$ : クーロン摩擦力, $t_{l}$ : 負荷力, $x$ は出力位置である。 また，各パラメータが動作中に変動すると考えると

$$
\begin{aligned}
& R_{a}=R_{a n}+\Delta R_{a} \\
& K_{v}=K_{v n}+\Delta K_{v} \\
& K_{t}=K_{v n}+\Delta K_{v} \\
& M=M_{n}+\Delta M \\
& F_{v}=F_{v n}+\Delta F_{v}
\end{aligned}
$$

と表すことができる。ここで, 添え字 ${ }_{n}$ のは公称值を表し, $\Delta$ は変動分を示している。

本モー夕の諸係数の公称值を表 1 に示す。各パラメータ の変動分は，動作状態および電機子位置により著しく左右 されると考えられる。

$\langle\mathbf{2} \cdot 2\rangle$ 等価外乱本モータの静特性として推力測定 を行った結果を図 1 に示す。推力はバネばかりで測定し, レール上の異なる 5 点において測定した平均值である。図 1 のようにブラシと整流子間の摩擦の影響により, 約 2.5 [A] 以下の電流ではモー夕は動作しないことから，非線形特性

表 1 供試リニアモータのパラメータ

Table 1. Parameters of tested motor.

\begin{tabular}{llll}
\hline Specifications & & & \\
voltage & & 24 & $\mathrm{~V}$ \\
current & & 5.0 & $\mathrm{~A}$ \\
speed & & 0.6 & $\mathrm{~m} / \mathrm{sec}$ \\
Parameters & & & \\
armature resistance & $R_{a n}$ & 2.70 & $\Omega$ \\
armature inductance & $L_{n}$ & 4.14 & $\mathrm{mH}$ \\
mass & $M_{n}$ & 0.30 & $\mathrm{kgf}$ \\
voltage drop of bursh & $v_{b}$ & 0.898 & $\mathrm{~V}$ \\
back electromotive & $K_{v n}$ & 0.732 & $\mathrm{~V} / \mathrm{m} / \mathrm{sec}$ \\
force constant & & & \\
thrust constant & $K_{t n}$ & 0.732 & $\mathrm{~N} / \mathrm{A}$ \\
viscus friction coef- & $F_{v n}$ & 0.712 & $\mathrm{~N} / \mathrm{m} / \mathrm{sec}$ \\
ficient & & & \\
Coulomb friction & $t_{c}$ & 0.896 & $\mathrm{~N}$ \\
\hline
\end{tabular}


を有していることが確認できる。そこで, 本位置決めシス テムにおける外乱として，実際の負荷力に加えて静特性に より示される非線形特性の影響ならびにパラメータ変動を 考慮した等価外乱 $d$ を次式のように定義する。

$$
\begin{aligned}
d & =K_{t n} i-\left(M_{n} \frac{d v}{d t}+F_{v n} v\right) \\
& =\Delta M \frac{d v}{d t}+\Delta F_{v} v+t_{c}+t_{l}-\Delta K_{t} i
\end{aligned}
$$

本システムの操作量は電機子電圧 $u$ なので, マッチング 条件を満足するように等価外乱 $d$ を電圧換算すると次式の ように表すことができる。

$$
d^{\prime}=\frac{\Delta R_{a}}{K_{t n}}\left(M_{n} \frac{d v}{d t}+F_{v n} v\right)+\Delta K_{v} v+v_{b}+\frac{R_{a}}{K_{t n}} d
$$

(10) 式の電圧換算された等価外乱 $d^{\prime}$ は実システムの特性 と公称值を用いた線形特性との差を意味しており，等価外 乱の影響を十分に抑圧できれば制御対象を線形モデルとし て取り扱うことができる。

$\langle\mathbf{2} \cdot \mathbf{3}\rangle$ 状態方程式 本リニアモータの状態方程式は 方程式は (1)〜 (10) 式より次式のように与えられる。

$$
\left.\begin{array}{l}
{\left[\begin{array}{l}
\dot{x} \\
\dot{v}
\end{array}\right]=\left[\begin{array}{ll}
0 & 1 \\
0 & a
\end{array}\right]\left[\begin{array}{l}
x \\
v
\end{array}\right]+\left[\begin{array}{l}
0 \\
b
\end{array}\right]\left(u-d^{\prime}\right)} \\
\dot{\mathbf{x}}=\mathbf{A x}+\mathbf{B}\left(u-d^{\prime}\right)
\end{array}\right\} .
$$

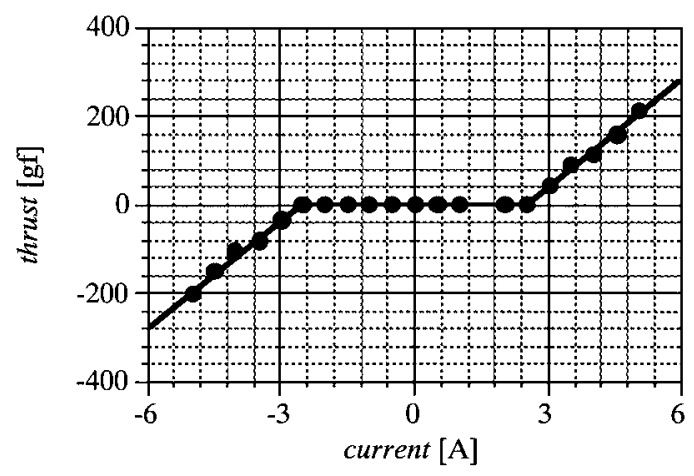

図 1 電機子電流-推力特性

Fig. 1. Static characteristic of armature current to thrust.

$$
\begin{aligned}
& \text { ここで, } \\
& a=-\frac{R_{a n} F_{v n}+K_{t n} K_{v n}}{R_{a n} M_{n}} \ldots \\
& b=\frac{K_{t n}}{R_{a n} M_{n}} \ldots \ldots \ldots \ldots \\
& \left|d^{\prime}\right| \leq \rho_{0} \ldots \ldots \ldots \ldots \ldots
\end{aligned}
$$

とし，等価外乱 $d^{\prime}$ の最大值 $\rho_{0}$ は既知として設計を行う。

\section{2 自由度位置決めシステムの設計}

図 2 に提案するリニア DC モー夕 2 自由度位置決めシス テムのブロック線図を示す。ここで， $u_{m}$ : 規範モデルへの 入力, $x_{m}$ : 規範モデルの出力位置, $e_{x}: x_{m}$ と $x$ の偏差で ある。

また，図中のリニア DC モータの数学モデルに用いてい る $K, \tau$ と状態方程式中のパラメータ $a, b$ との関係は

$$
(K, \tau)=\left(-\frac{b}{a},-\frac{1}{a}\right)
$$

と表される。

本システムはモデル規範形 SMC により構成されるフィー ドバックコントローラに固定ゲインフィードフォワードコ ントローラ $F(s)$ を付加した 2 自由度制御システムである。 リニアモータの望ましい動特性を規範モデルとして与え, モデルの出力にリニアモータの出力位置が一致するように 各コントローラの設計を行う。各コントローラの設計には 表 1 に示した各パラメータのノミナル值を用いており，パ ラメータ変動は等価外乱に含まれるものとして設計してい る。以下に規範モデル, SMC, フィードフォワードコント ローラの設計手法について述べる。

〈3・1〉規範モデルの設計＼cjkstart規範モデルを次式のよう な状態方程式として定義する。

$$
\left.\begin{array}{l}
{\left[\begin{array}{l}
\dot{x}_{m} \\
\dot{v}_{m}
\end{array}\right]=\left[\begin{array}{cc}
0 & 1 \\
0 & a_{m}
\end{array}\right]\left[\begin{array}{l}
x_{m} \\
v_{m}
\end{array}\right]+\left[\begin{array}{c}
0 \\
b_{m}
\end{array}\right] u_{m}} \\
\dot{\mathbf{x}}_{m}=\mathbf{A}_{m} \mathbf{x}_{m}+\mathbf{B}_{m} u_{m}
\end{array}\right\}
$$

ここで, $u_{m}$ : 規範モデルへの速度指令入力 $[\mathrm{m} / \mathrm{s}], v_{m}$ : 規 範モデルの速度出力 $[\mathrm{m} / \mathrm{s}], x_{m}$ : 規範モデルの出力位置 $[\mathrm{m}]$ である。また，規範モデルは制御対象であるリニアモー夕

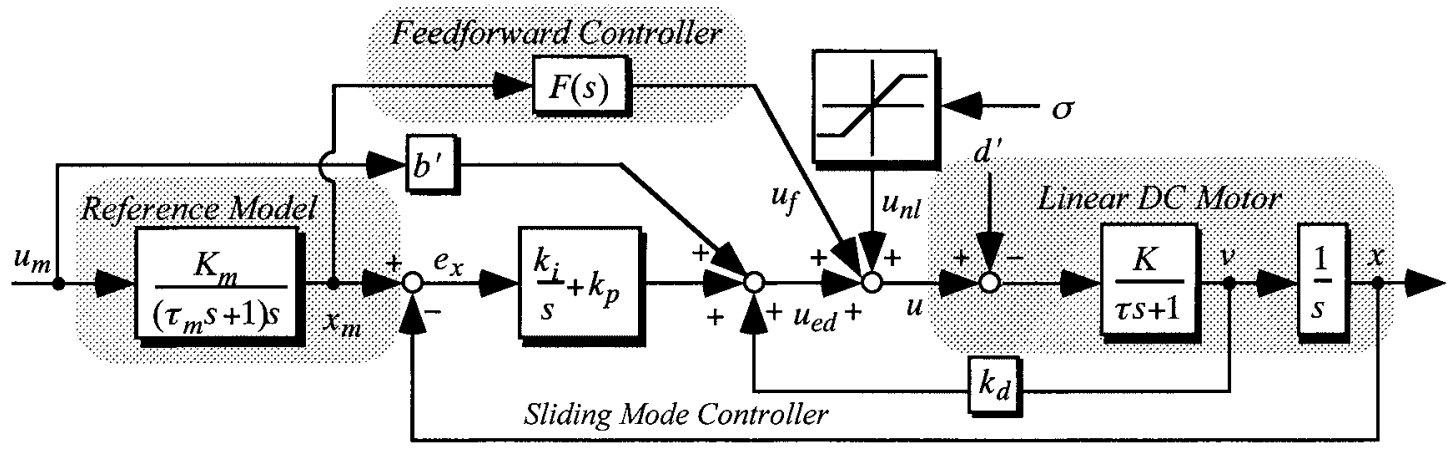

図 2 リア DC モータ 2 自由度位置決めシステム

Fig. 2. Block diagram of proposed positioning system. 
の線形モデルと同次数に設定している。このことにより設 計パラメータである $a_{m}, b_{m}$ は設計者が設定する規範モデ ルの既知パラメータであるが，特に制御対象のノミナル值 から導出される時定数 $\tau$ を考慮して設定することになる。 図中の $K_{m}, \tau_{m}$ との関係は次式のように表される。

$$
\left(K_{m}, \tau_{m}\right)=\left(-\frac{b_{m}}{a_{n}},-\frac{1}{a_{m}}\right) .
$$

また，リニアモータの数学モデルのゲイン定数 $K$ および 時定数 $\tau$ は前述の表 1 に示しているモータのノミナル值か ら導出すると次のような值となる。

$$
(K, \tau)=(0.261,0.226)
$$

このとき，本システムの状態誤差 $\mathbf{e}=\left[\begin{array}{ll}e_{x} & e v\end{array}\right]^{\mathrm{T}}$ を次の ように定義する。

$$
\begin{aligned}
& e_{x}=x_{m}-x \\
& e_{v}=v_{m}-v
\end{aligned}
$$

(19)，(20) 式で表される誤差信号をそれぞれ微分すると次 式のように表すことができる。

$$
\begin{aligned}
\dot{e}_{x} & =e_{v} \ldots \ldots \ldots \ldots \ldots \ldots \ldots \ldots \ldots \ldots \ldots \\
\dot{e}_{v} & =\dot{v}_{m}-\dot{v} \\
& =a_{m} e_{v}+\left(a_{m}-a\right) v+b_{m} u_{m}-b\left(u-d^{\prime}\right) \ldots \ldots
\end{aligned}
$$

〈3·2〉 スライディングモードコントローラの設計 $\langle\mathbf{3} \cdot \mathbf{2} \cdot \mathbf{1}\rangle$ 等価制御入力の設計 (11) 式，(16)より対 $(\mathbf{A}, \mathbf{B})$ と $\left(\mathbf{A}_{m}, \mathbf{B}_{m}\right)$ は可制御性を示すので，スライディング モードの存在条件を満足する。まず，等価制御入力 $u_{e d}$ の 設計を行うにあたり, 誤差空間での切換平面 $\sigma$ を次式のよ うに定義する。ただ，定常偏差を消去する目的で出力位 置誤差 $e_{x}$ の積分值 $z_{x}$ を加えた状態誤差 $\mathbf{e}^{\prime}=\left[\begin{array}{lll}e_{x} & e_{v} & z_{x}\end{array}\right]^{\mathrm{T}}$ を用いて切換平面を設計する。

$$
\sigma=\mathbf{S e}^{\prime}=s_{1} e_{x}+s_{2} e_{v}+s_{3} z_{x}
$$

ここで， $\sigma$ は切換平面の法線ベクトルであり，

$$
\mathbf{S}=\left[\begin{array}{lll}
s_{1} & s_{2} & s_{3}
\end{array}\right]
$$

と表される。また，(23) 式を微分すると，

$$
\begin{aligned}
\dot{\sigma}= & s_{1} \dot{e}_{x}+s_{2} \dot{e}_{v}+s_{3} e_{x} \\
= & \left(s_{1}+a_{m} s_{2}\right) e_{v}+s_{3} e_{x} \\
& +s_{2}\left\{\left(a_{m}-a\right) v+b_{m} u_{m}-b\left(u-d^{\prime}\right)\right\}
\end{aligned}
$$

本システムにおいてスライディングモードを生じている, つまり, 切換平面 $\sigma$ 上に状態誤差 $\mathbf{e}^{\prime}$ が存在すると仮定する と次式が成立する。

$$
\sigma=\dot{\sigma}=0
$$

このとき，等価外乱 $d^{\prime}$ はスライディングモードコントロー ラのハイゲイン特性により零になり, 制御入力 $u$ は等価制
御入力 $u_{e d}$ として取り扱うことができる。また，等価制御 入力 $u_{e d}$ は, (25), (26) 式より次式のように速度フィード バックループと規範モデルへの入力 $u_{m}$ からのフィードフォ ワード要素を付加した位置誤差 $e_{x}$ に対する PI コントロー ラで表すことができる。

$$
u_{e d}=k_{i} z_{x}+k_{p} e_{x}+k_{d} v+b^{\prime} u_{m}
$$

ただし，

$$
\begin{aligned}
k_{i} & =-\frac{s_{3}\left(s_{1}+s_{2} a_{m}\right)}{b s_{2}^{2}} \ldots \ldots . \\
k_{p} & =\frac{s_{2} s_{3}-s_{1}\left(s_{1}+s_{2} a_{m}\right)}{b s_{2}^{2}} . \\
k_{d} & =\frac{a_{m}-a}{b} \ldots \ldots \ldots \ldots \ldots \ldots \ldots \\
b^{\prime} & =\frac{b_{m}}{b} \ldots \ldots \ldots \ldots \ldots
\end{aligned}
$$

である。ここで，後述のフィードフォワードコントローラ $F(s)$ により (27) 式中のフィードフォワード要素 $b^{\prime} u_{m}$ の影 響は相殺しており，等価制御入力として機能している。この とき，スライディングモード時の誤差方程式は (21), (22), (26) 式により次式のように求められる。

$$
\begin{aligned}
& \left.\left[\begin{array}{c}
\dot{e}_{x} \\
\dot{e}_{v}
\end{array}\right]=\left[\begin{array}{cc}
0 & 1 \\
-\frac{s_{3}}{s_{2}} & -\frac{s_{1}}{s_{2}}
\end{array}\right]\left[\begin{array}{l}
e_{x} \\
e_{v}
\end{array}\right]\right\} . \\
& \dot{\mathbf{e}}=\mathbf{A}_{\mathrm{e}} \mathbf{e}
\end{aligned}
$$

上式より $\mathbf{A}_{\mathrm{e}}$ 行列の特性方程式が安定極を有するように 切換平面 $\sigma$ を設計すれば，この誤差システムは原点に収束 し，等価制御入力のフィードバックゲインを一意に決定す ることができる。本研究においては, 真鍋多項式を用いた 切換平面の設計を行っている。その結果, 法線ベクトルの 比は真鍋多項式における等価時定数をとすると

$$
\left.\begin{array}{l}
\frac{s_{1}}{s_{3}}=\tau_{c} \\
\frac{s_{1}}{s_{2}}=\frac{2.5}{\tau_{c}}
\end{array}\right\}
$$

\section{として求めることができる。}

$\langle\mathbf{3 \cdot 2 \cdot 2}\rangle$ 切換制御入力の設計 切換制御入力の設計 においてはチャタリング防止の対策として切換制御入力 $u_{n l}$ を図 3 に示すような飽和関数とし，次式により与えられる。

$$
u_{n l}= \begin{cases}\frac{\sigma}{|\sigma|} \rho & (|\sigma|>\delta) \\ \frac{\sigma}{\delta} \rho & (|\sigma| \leq \delta)\end{cases}
$$

ここで, $\delta$ はチャタリングを防止するための小さな定数で ある。また, $\rho>0$ は切換制御入力の振幅を表しており, 漸 近安定性を保証するためには $\rho>\rho_{0}$ を満足する必要がある。 そこで，本システムにおいては，次に示す条件により (10) 式に基づいて $\rho_{0}$ を導出している。まず，パラメータ変動幅 はノミナル值の $50 \%$ とし, 出力速度 $v$ は定格速度 $0.6[\mathrm{~m} / \mathrm{s}]$, 出力加速度 $\dot{v}$ はリニアモータの線形モデルより定格電圧を 


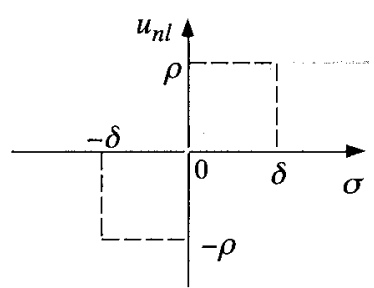

図 3 飽和関数を用いた切換超平面

Fig. 3. Swiching hyperplane using saturation function.

印可した場合の最大加速度として得られた $2.65\left[\mathrm{~m} / \mathrm{s}^{2}\right]$ とし た。また, 摩擦の大部分を占めるクーロン摩擦力は, 図 1 の 静特性から得られた電機子電流の不感带幅約 2.5 [A] より導 出している。これらの条件により等価外乱 $d^{\prime}$ は約 $9.92[\mathrm{~V}]$ と求められ， $\rho_{0}$ を $10[\mathrm{~V}]$ として実測を行っている。

$\langle\mathbf{3} \cdot \mathbf{3}\rangle$ フィードフォワードコントローラ $F(s)$ の設計

モデル規範形 SMCにより等価外乱が抑圧され伝達特性 が固定されると仮定すると，規範モデルへの入力 $u_{m}$ から 出力位置 $x$ までの開ループ伝達関数は次式のように表わさ れる。

$$
\frac{K m}{\left(\tau_{m} s+1\right) s}\left\{f(s)+\frac{b^{\prime}\left(\tau_{m} s+1\right) s}{K_{m}}\right\} \frac{K}{\left(\tau s+1-K_{d}\right) s}
$$

ここで，モデルへの入力 $u_{m}$ から $x$ までの伝達関数を規範 モデルに一致させるように，つまり，次式のように(35) 式 の第 2 項，第 3 項の積が 1 になるように $F(s)$ を設計する。

$$
\left\{F(s)+\frac{b^{\prime}\left(\tau_{m} s+1\right) s}{K_{m}}\right\} \frac{K}{\left(\tau s+1-K k_{d}\right) s}=1
$$

上式よりフィードフォワードコントローラは次式のように 導出することができる。

$$
f(s)=\frac{\tau}{K} s^{2}+\frac{1-K k_{d}}{K} s-\frac{b^{\prime}\left(\tau_{m} s+1\right) s}{K_{m}} \cdots \cdots \cdots
$$

等価外乱が $\mathrm{SMC} に よ り$ 抑圧され，上式のように $F(s)$ を設 計すればシステムの伝達特性は規範モデルと一致すること になる。よって，規範モデルは理論上任意に設定すること が可能となるが，現実的には電流等のハードウェアの制限 を受けることになる。また，(37) 式より (27) 式中のフィー ドフォワード補償 $b^{\prime} u_{m}$ を相殺していることも確認できる。 なお，コントローラの構成上，モデルの速度出力 $v_{m}$ の 1 階 微分 $\dot{v}_{m}$ が必要となる。

よって, 本 2 自由度位置決めシステムの制御入力 $u$ は次 式で示すように等価制御入力 $u_{e d}$ と切換制御入力 $u_{n l}$ 㧍よ びフィードフォワード補償入力 $u_{f}$ の和となる。

$$
u=u_{e d}+u_{n l}+u_{f}
$$

\section{4. 実測システム}

図 4 に実測に用いた位置決めシステムのハードウェア構

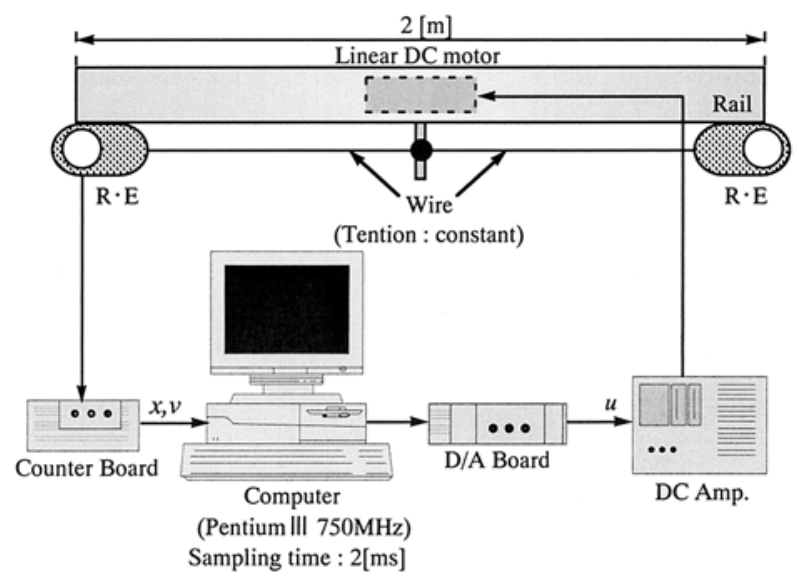

図 4 実測システム

Fig. 4. Experimental system.

成を示す。実測システムは, 供試りニアモータ, ロータリー エンコーダ，カウンタボード拉よび $\mathrm{D} / \mathrm{A}$ 変換ボードを搭載 した制御用計算機，直流増幅器から構成されている。 $2 \mathrm{~m}$ のレールを持つリニア DC モータの両端に張力一定のワイ ヤーを介してロータリーエンコーダ $(50 \mathrm{pulse} / \mathrm{cm})$ が接続さ れている。電機子の位置掞よび速度はカウンタボードによ り演算され制御用計算機に取り込まれる。計算機内で処理 された操作量は 12 ビットの $\mathrm{D} / \mathrm{A}$ 変換ボードを介して直流 増幅器にてゲイン倍された後に電機子に供給される。直流 増幅器のゲインは 3.0 に, また, SMC およびフィードフォ ワードコントローラは $\mathrm{C}$ 言語を用いてソフトウェア上で実 現されている。

\section{5. 応答特性}

$\langle\mathbf{5} \cdot \mathbf{1}\rangle$ 目標值追従特性前述した設計手順に従いモ デル規範形 SMC とフィードフォワードコントローラの設 計を行った。実測時に用いた設定パラメータは，規範モデ ルのパラメータである $K_{m}=1.0, \tau_{m}=0.15$ に, 特性方 程式の等価時定数を $\tau_{c}=0.6[\mathrm{~s}]$, 切換制御入力の振幅を $\rho=12.0[\mathrm{~V}] ， \delta=0.03$ に設定している。

まず，本制御システムに㧍ける実測結果を図 5 に示す。 ここで，規範入力 $u_{m}$ として図 5 に示すような方形波状規 範入力 (振幅 $0.3[\mathrm{~m} / \mathrm{s}]$, 周期 $1.5[\mathrm{~s}]$ ) 規範モデルに入力して 実測を行っている。従来の固定ゲインフィードコントロー ラを用いた制御系では，摩擦による不感帯のため大きな時 間遅れが問題であったが，図 5(a) に示す提案する 2 自由度 位置決めシステムの応答特性では, モデルの出力 $x_{m}$ に遅れ なく追従していることが確認できる。この結果より，提案 するシステムによって摩擦による不感帯の影響を抑圧しつ つ良好な目標值追従特性を得られることが確認できる。ま た，図 5(b) ( (e) には各制御信号と追従誤差，切換関数の時 間応答を示している。追従誤差 $e_{x}$ ならびに切換関数 $\sigma$ は 定常状態に落ち着くまでは零付近で振動しているもののほ ぼ零に収束していることが確認できる。さらに，制御信号 


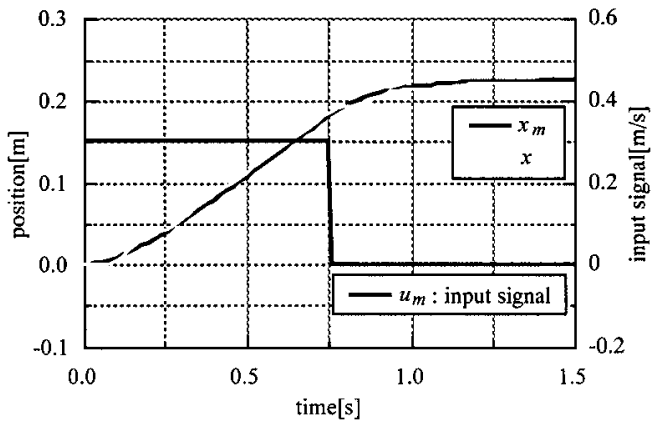

(a) Desired output $x_{m}$ and actual output $x$.

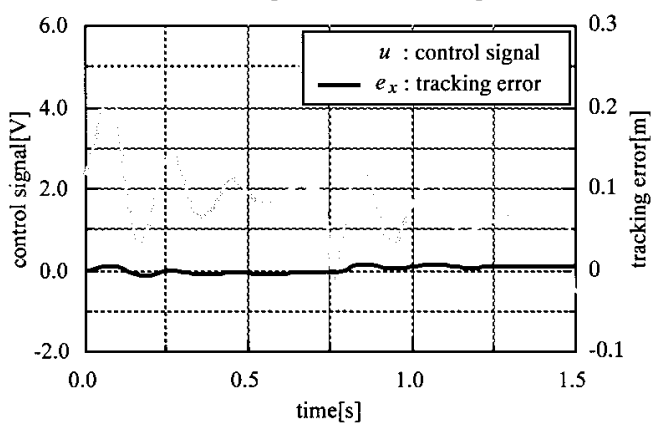

(b) Control signal $u$ and tracking error $e_{x}$.

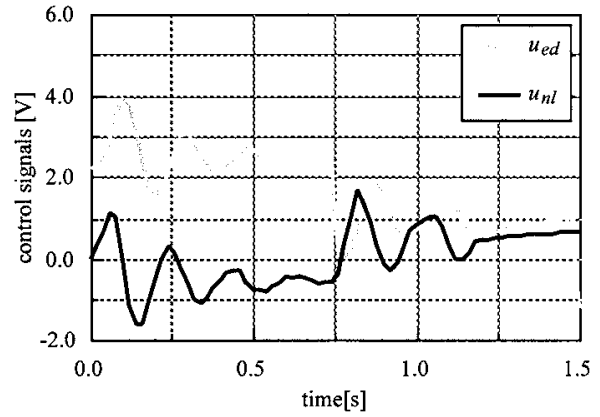

(c) Control signals $u_{e d}$ and $u_{n l}$.

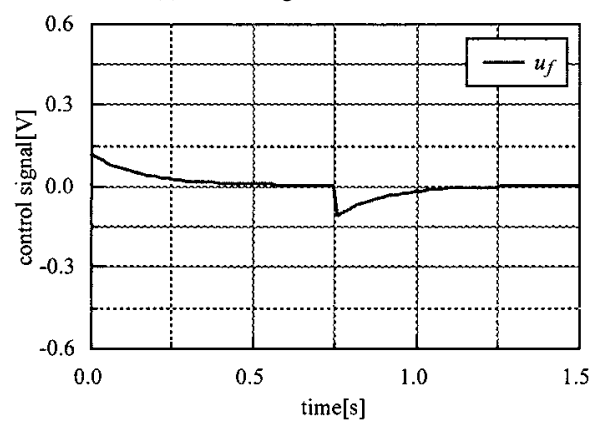

(d) Control signal $u_{f}$.

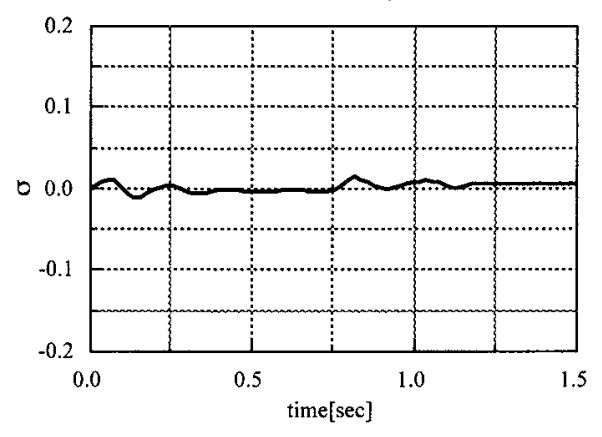

(e) Response of switching function $\sigma$.

図 5 方形波状入力に対する応答特性

Fig. 5. Experimental results for square wave input. $u$ が大きく振動しているが, 切換平面近傍での振動が原因 だと考えられる。チャタリング防止のための切換制御入力 のパラメータである $\delta$ をさく設定すると振動を伴うもの の位置決め特性が向上する。逆に， $\delta$ を大きく設定すると 振動が抑制されるものの外乱抑圧特性が損なわれ，位置決 め精度が劣化する。本実測に抒いては，試行錯誤的に $\delta$ を 決定している。また, フィードフォワード要素 $b^{\prime} u_{m}$ の影響 を相殺しているため，フィードフォワード補償入力 $u_{f}$ は 切換制御入力や等価制御入力に対して非常に小さな信号と なっていることに注意されたい。

図 6 には，提案する固定ゲインフィードフォワードコン トローラ $F(s)$ を付加した位置決めシステムの応答特性と $\mathrm{SMC}$ のみの応答特性を比較している。モデル規範形 SMC のみのシステムでは立ち上がり時の時間遅れが約 0.1 [s] 程 度あるものの, 提案する 2 自由度位置決めシステムにおい ては, モデルの出力 $x_{m}$ に遅れなく追従していることが確 認できる。この結果より，フォードフォワードコントロー ラ $F(s)$ により追従特性の改善が図られていることが確認で きる。

また，モデルのパラメータ $\tau_{m}$ を変化させた場合の応答特 性を図 7 に示す。ここで, モデルの時定数である $\tau_{m}$ によ る実測結果の差異を明確にするために，規範モデルへの入 力 $u_{m}$ の周期を $2.0[\mathrm{~s}]$ に設定して実測を行っている。その ため，モデルの出力位置 $x_{m}$ の定常值がこれまでの実測結 果に対して若干大きくなっているが，その他設定パラメー 夕の值は，前述の実測時と同じ值に設定している。実測結

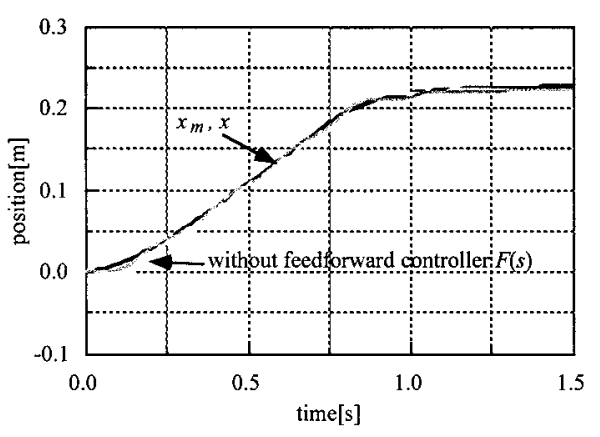

困 $6 F(s)$ の効果

Fig. 6. Effect of the feedforward controller $F(s)$.

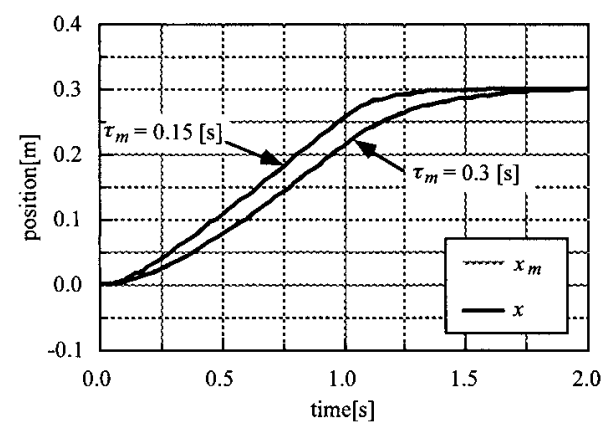

図 7 モデルパラメータ $\tau_{m}$ の影響

Fig. 7. Influence of parameters of model. 


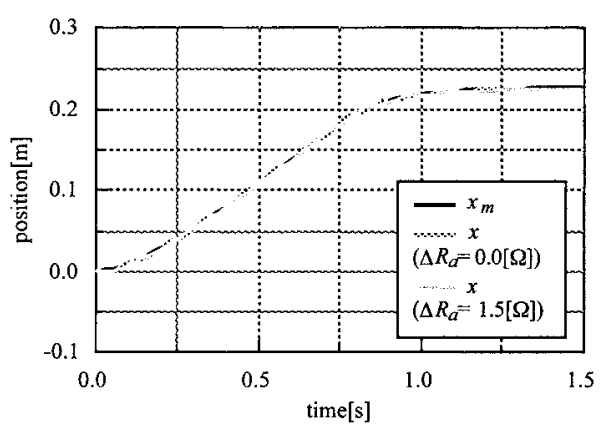

図 8 電機子抵抗変化に対する応答特性

Fig. 8. Experimental results for transition of armature resistance.

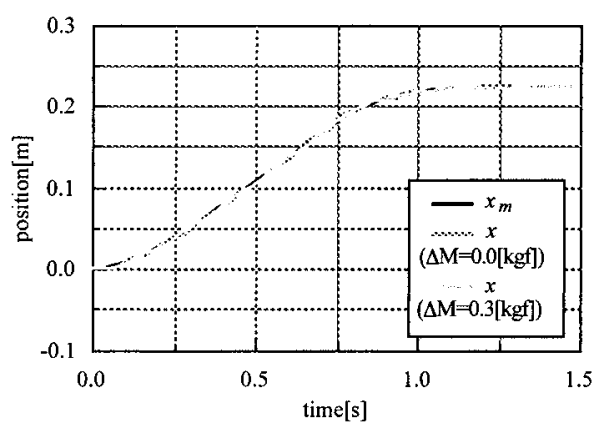

図 9 モー夕質量変化に対する応答特性

Fig. 9. Experimental results for transition of mass.

果より，立ち上がり時間を変化させても，規範モデルの出 力 $x_{m}$ に対して出力位置 $x$ は遅れなく追従していることが 確認できる。従って，モデルの設定パラメー夕に依存せず 良好な位置決めが可能であることが確かめられた。

$\langle\mathbf{5} \cdot \mathbf{2}\rangle$ 外乱抑圧特性 本システムの外乱抑圧特性を 検証するため，電機子抵抗および慣性負荷の変化に対する 応答特性を実測した。図 8 に電機子抵抗に直列に負荷抵抗 を装着した場合の応答特性を示す。負荷抵抗としてノミナ ル值の約 $55 \%$ に相当する $1.5[\Omega]$ を装着して実測を行った。 負荷抵抗未装着時と比較して応答特性に変化が現れないこ とから，電機子抵抗の変化に対してロバストであることが 確認できる。また，慣性負荷を装着した場合の応答特性を 図 9 に示す。慣性負荷としてノミナル值の約 $100 \%$ に相当 する $0.3[\mathrm{kgf}]$ の重りを装着して実測を行った。慣性負荷未 装着時と比較して応答特性に変化が現れないことから, 慣 性負荷の変化に対してロバストであることが確認できる。 これらの結果から，モデル規範形 SMCにより摩擦による 非線形特性に加えパラメータ变動の影響が十分抑圧され， リニアモータの伝達特性は公称值で表される線形特性に固 定できることが検証された。

\section{6. まとめ}

本稿では，ブラシと整流子間の摩擦による不感帯の影響 が問題となるリニア DC モー夕を制御対象とし，モデル規範 形 SMC を用いた 2 自由度位置決めシステムの設計法につ
いて検討し，実測結果から本システムの有用性を確認した。 まず，設計手順として摩擦による非線形特性に加えパラ メータ変動の影響を等価外乱とみなし，マッチング条件を 満足していることを確認した。その上で，システムの望ま しい動特性を決定する規範モデルを定義し，スライディング モード時に状態誤差が原点に収束するように等価制御入力 を設計した。このとき，等価制御入力はPI コントローラに 速度フィードバックループとフィードフォワード要素を付 加したフィードバック制御システムにて表される。フィー ドバック制御系の各ゲインは, 係数図法の一手法である真 鍋多項式を用いて誤差システムが安定となるように設計さ れる。誤差システムの収束性は, 真鍋多項式の等価時定数 により決定される。また，切換制御入力はチャタリングを 防止する目的で飽和関数を用いて設計を行っている。モデ ル規範形 SMC により摩擦等の非線形特性に加えパラメー 夕変動を含めた等価外乱を十分に抑圧すれば，リニアモー 夕の伝達特性は公称值で表される線形特性に固定できる。 そこで, 規範モデルの入力からリニアモータの出力位置ま での伝達特性を規範モデルと一致するようにフィードフォ ワードコントローラを設計することにより，良好な目標值 追従特性を得ることができる。つまり，フィードフォワー ドコントローラを付加することにより, 理論上規範モデル を任意に設定できることになる。しかしながら，現実的に はハードウェアの制限を受け, 設定範囲は限られることに なる。

実測結果から，摩擦の影響ならびにパラメータ変動に対 してロバストであることを実証し，提案するモデル規範形 SMC を用いた 2 自由度位置決めシステムにより高精度な 位置決め特性が得られることを確認した。

\section{謝 辞}

本研究の一部が南海育英会ならびに高松高専教育研究助 成会の補助を受けたことも併せて記し，謝意を表す。

(平成 17 年 3 月 30 日受付, 平成 17 年 10 月 3 日再受付)

\section{文献}

（1）電気学会磁気アクチュエー夕調査委員会：「リニアモー夕とその応 用」, 電気学会 $(1993)$

（2）白木 学·宮尾修美：図解リニアモータとシステム設計, 総合電子 出版社 (1986)

(3) S. Urushihara, T. Kamano, T. Suzuki, and H. Harada: "Tracking Performance of a Positioning System with a Linear DC servo Motor using Neural Network", T. IEE Japan, Vol.115-D, No.3, pp.204-210 (1995-3) (in Japanese)

漆原史朗・鎌野环也・鈴木茂行・原田寛信：「ニューラルネットワー クを用いたリニア DC モータの位置決め特性」, 電学論 D, 115, 3, pp.204-210 (1995-3)

(4) S. Urushihara, T. Kamano, T. Suzuki, and H. Harada: "High-Performance Positioning System with a Linear DC servo Motor under Self-tuning Fuzzy Control", Electric Power Components and Systems, Vol.29, pp.145-161 (2001-5)

（5）住友重機械工業（株）総合技術研究所：「外乱オブザーバを用いたリ ニアモータステージの制御」, 技術報告書

（6）野波健蔵・田 宏奇：スライディングモード制御, コロナ社 (1994)

（7）増淵正美・川田誠一：システムのモデリングと非線形制御, コロナ 社 (1996) 
（8）野波健蔵：MATLAB による制御系設計, 東京電機大学出版社 (1998)

(9) S. Yura, T. Kamano, T. Yasuno, T. Suzuki, H. Harada, and S. Urushihara: "Swing up and Stability Control of Inverted Pendulum with Inertia Rotor under Energy Control and Sliding Mode Schemes", T. IEE Japan, Vol.121-D, No.8, pp.957-966 (2001-8) (in Japanese)

由良諭・鎌野环也·安野 卓 - 鈴木茂行 - 原田寬信 - 漆原史朗 : 「エネルギー法とスライディングモードを用いた慣性ロータを有す る倒立振子の制御」, 電学論 D, 121, 8, pp.848-854 (2001-8)

(10) S. Yura, T. Kamano, S. Urushihara, T. Yasuno, T. Suzuki, and H. Harada: "A Design Method of Model Reference Type Sliding Mode Controller for Twomass Servo System", IEEJ Trans. IA, Vol.123, No.3, pp.219-226 (2003-3) (in Japanese)

由良 諭・鎌野玩也·漆原史朗・安野 卓・鈴木茂行・原田寛信：「二 慣性速度サーボシステムに対するモデル規範形スライデイングモー ドコントローラの一設計法」, 電学論 D, 123, 3, pp.219-226 (2003-3)

(11) V.I. Utkin: "Variable Structure Systems with Sliding Modes", IEEE Transactions on Automatic Control, pp.212-222 (1977-4)

(12) 堀 洋一 ·大西公平 : 制御工学の基礎, 丸善 (1997)

(13) Y. Hori: "2-Inertia System Control using Resonance Ratio Control and Manabe Polynomials", T. IEE Japan, Vol.114-D, No.10, pp.1038-1045 (199410) (in Japanese)

堀 洋一：「共振比制御と真鍋多項式による 2 慣性系の制御」,電学 論 D, 114, 10, pp.1038-1045 (1994-10)

（14） 真鍋舜治：係数図法のメカトロニクス設計への応用, 計測自動制御 学会第 20 回ロボット工学部会研究会 (1993)

\section{付 録}

\section{安定性解析}

本システムでは，(10) 式のようにマッチング条件が成立 している。この条件下でリアプノフ関数の候補 $V$ を

$$
V=\frac{1}{2} \sigma^{2} \ldots \ldots \ldots \ldots \ldots \ldots \ldots \ldots \ldots \ldots \ldots \ldots
$$

とする。ここで， $|\sigma|>\delta$ のとき (25) 式より次式のように $V$ の微分 $\dot{V}$ が求められる。

$$
\begin{aligned}
\dot{V}= & \sigma \dot{\sigma}=\sigma \mathbf{S} \dot{\mathbf{e}}^{\prime} \\
= & \sigma\left[\left(s_{1}+a_{m} s_{2}\right) e_{v}+s_{3} e_{x}\right. \\
& \left.+s_{2}\left\{\left(a_{m}-a\right) v+b_{m} u_{m}-b\left(u_{e d}+u_{n l}-d^{\prime}\right)\right\}\right]
\end{aligned}
$$

(付 2) 式に (27)〜(31)，(34) 式を代入すると

$$
\dot{V}=-\sigma s_{2} b\left(\frac{\sigma}{|\sigma|} \rho-d^{\prime}\right)=s_{2} b\left(|\sigma| \rho-\sigma d^{\prime}\right) \cdots
$$

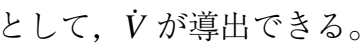

ここで, $s_{2} b>0$ が常に成り立っているため, $\dot{V}<0$ を満 足するためには

$$
|\sigma| \rho-\sigma d^{\prime}>0 \cdots
$$

を満たせばよい。

よって, $\left|d^{\prime}\right| \leq \rho_{0}$ より切換制御入力の振幅 $\rho$ を

$$
\rho>\rho_{0}
$$

に設定すれば， $\dot{V}<0$ を満足し，任意の初期条件からシス テムの状態量を切換平面に拘束する十分条件を満たす。

一方， $|\sigma|<\delta$ の場合， $\delta$ が十分小さければ安定性を保証 できる。よって，本システムでは，(付 5) 式を満足するよう に設定を行っているので漸近安定が補償されることになる。
また，(付 5) 式を満足し，スライディングモードを生じ るとき，等価外乱 $d^{\prime}$ は抑圧されるとともにシステムの状態 量は切換平面上に拘束される。このとき, 制御入力 $u$ は次 式で表される。

$$
\begin{aligned}
u & =u_{e d}+u_{n l}+u_{f}-d^{\prime} \\
& =u_{e d}+u_{f} \ldots \ldots \ldots
\end{aligned}
$$

ここで, $u_{e d}$ は等価制御入力, $u_{n l}$ は切換制御入力, $u_{f}$ は フィードフォワード補償入力, $d^{\prime}$ は等価外乱である。(26) (31) および (37) 式より，は次式のように表すことができる。

$$
\begin{array}{r}
u_{e d}=\frac{1}{b}\left\{\frac{s_{3}}{s_{2}} e_{x}+\left(s_{1}+a_{m} s_{2}\right) e_{v}+\left(a_{m}-a\right) v+b_{m} u_{m}\right\} \\
\ldots \ldots \ldots \ldots \ldots \ldots \text { (付 } 7) \\
\left.u_{f}=\frac{1}{b}\left(\dot{v}_{m}-a_{m} v_{m}-b_{m} u_{m}\right) \cdots \ldots \ldots \ldots \ldots \text { (付 } 8\right)
\end{array}
$$

(付 6) ( 付 8), (11) 式より, 次式が求められる。

$$
\dot{v}=\frac{s_{3}}{s_{2}} e_{x}+\frac{s_{1}}{s_{2}} e_{x}+\dot{v}_{m}
$$

(付 9) 式は，(32) 式の誤差方程式を示している。つまり, (32) 式の特性方程式が安定極を有するように設計していれ ば，フィードフォワード補償を付加しても同様に誤差シス テムが原点に収束することとなり，システムは安定性を有 していることになる。

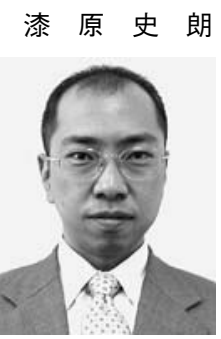

（正員） 1969 年生。1997 年 3 月德島大学大学院 工学研究科システム工学専攻博士後期課程修了。 同年 4 月 (株) 片岡機械製作所入社。1998 年 7 月 高松工業高等専門学校電気工学科講師, 2005 年 4 月助教授, 現在に至る。主としてインテリジェン ト制御システムの研究に従事。博士 (工学)。計 測自動制御学会, 日本機械学会会員。

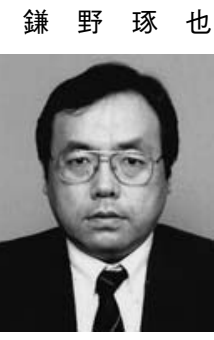

（正員） 1957 年生。1982 年 3 月九州大学大学院 工学研究科電気工学専攻修士課程修了。1983 年 9 月同研究科博士課程退学。同年 10 月理徳島大学 工学部電気工学科助手, 1988 年 6 月講師, 1989 年 12 月助教授, 2003 年 1 月教授, 現在に至る。 主としてインテリジェント制御システムの研究に 従事。工学博士。計測自動制御学会, システム制 御情報学会, 日本ロボット学会, 日本ファジィ学 会, 日本機械学会, 日本太陽エネルギー学会会員。

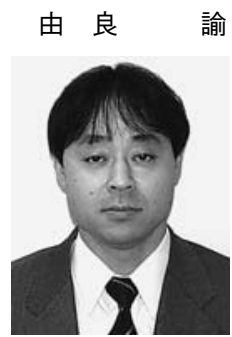

諭（正員） 1966 年生。1991 年 3 月徳島大学大学院 工学研究科電気工学専攻修士課程修了。同年 4 月 高松工業高等専門学校制御情報工学科助手, 1992 年 4 月講師, 2002 年 4 月助教授, 現在に至る。主 にモーションコントロール，メカトロニクスの研 究・教育に従事。博士 (工学)。計測自動制御学 会, 日本ロボット学会, 日本機械学会会員。 
安 野 卓 (正員) 1968 年生。1993 年 3 月徳島大学大学院

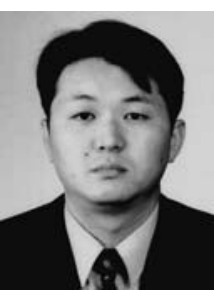

工学研究科電気電子工学専攻博士前期課程修了。 1993 年 12 月同研究科システム工学専攻博士後期 課程退学。1994 年 1 月徳島大学電気電子工学科助 手, 2001 年 12 月講師, 2004 年 1 月助教授, 現在 に至る。主としてインテリジェント制御システム の研究に従事。博士 (工学)。計測自動制御学会, システム制御情報学会, 日本知能情報ファジィ学
鈴 木 茂 行 （正員） 1939 年生。1966 年 3 月徳島大学大学院

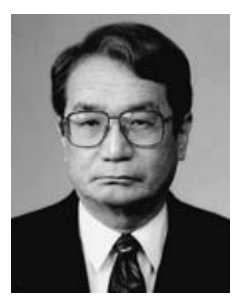
工学研究科電気工学専攻修士課程修了。徳島大学 工学部電気工学科助手, 講師, 助教授, 電気電子 工学科教授を経て現在, 德島大学名誉教授。各種 電動機の制御法，自然エネルギー利用のための制 御法開発などの研究に従事。工学博士。電子情報 通信学会, 計測自動制御学会, システム制御情報 学会, 日本太陽エネルギー学会会員。

会，日本ロボット学会，日本太陽エネルギー学会会員。 